\title{
Lumbricus terrestris L. distribution within an experimental humus mosaic in a mountain spruce forest
}

\author{
N. Bernier · J.-F. Ponge
}

\begin{abstract}
An experiment was designed at a mountain site to study the distribution of adult Lumbricus terrestris in relation to a small-scale mosaic of humus forms representative of different stages of a spruce forest ecosystem. Good agreement was found between distribution in the mosaic and that in the field. ANOVA tests demonstrated the strong influence of humus form on earthworm abundance when comparing a vermimull (high earthworm burrowing activity) taken from a spruce regeneration site (61.8 individuals $\left.\mathrm{m}^{-2}\right)$ with a leptomoder (no earthworm burrowing activity) taken from a 60-year-old spruce stand $\left(6.2\right.$ individuals $\left.\mathrm{m}^{-2}\right)$. Other humus forms were intermediate (mean density 34.6 individuals $\mathrm{m}^{-2}$ ). The same pattern was found with individual biomass, but with lower significance. Main differences observed in the experimental design were attributed to the immediate carrying density of the humus forms. A distinction was made between humus profiles built up with or without spruce cover. In the latter case (regeneration site and bilberry heath), the immediate carrying capacity indicated by the experimental approach overestimated the field density by a factor of 4 . Under spruce this overestimate was even higher (approximately 10 times too high in an adult spruce stand (160 years old) and 30 times too high under moss cover). The increase in density due to experimental conditions was not determined for leptomoder humus accumulated under the actively growing spruce stand (60 years old) since the earthworm density was near zero in both cases. Relationships between humus form and earthworm populations are discussed.
\end{abstract}

Key words Earthworm · Lumbricus terrestris $\cdot$ Spruce forest $\cdot$ Humus type $\cdot$ Mosaic dynamics

\footnotetext{
N. Bernier ( $)$ · J.-F. Ponge Museum National d'Histoire Naturelle, Laboratoire d'Ecologie Générale, 4 avenue du Petit-Château, F-91800 Brunoy, France, e-mail: Jean-Francois.Ponge@wanadoo.fr, Tel.: +33-1-60479214, Fax: +33-1-60465719
} 


\section{Introduction}

Earthworm populations are related to high levels of soil fertility (see review in Lee 1985). It can be assumed that either earthworms only thrive in fertile soils or that soil fertility is increased by earthworm activity (Robinson et al. 1991; Muys and Lust 1992; Basker et al. 1994). Since the work of Bornebusch (1930), burrowing earthworms have been closely associated with mull humus. The characteristics of the mull humus form mostly result from the burrowing activity of geophagous earthworms (Bal 1982). As soil properties and thus ecosystem productivity seem to depend so much on earthworm fauna, it is most important to understand the factors influencing their short-scale distribution. There are few data which relate improvement of a specific humus form to the natural development of earthworm populations. In a mountain spruce forest, Bernier and Ponge (1994) found evidence of a space/time mosaic pattern involving different humus forms (tightly linked with earthworm populations) and vegetation dynamics. The patchy distribution of earthworm populations could either be the result of individuals moving from place to place (migration) or differences in recruitment patterns (Marinissen and Van den Bosch 1992). The purpose of the present study was to test, by field bioassays, whether or not humus forms determined the patchy distribution of Lumbricus terrestris (L.).

\section{Materials and methods}

The study site

The experiment was conducted in a Norway spruce (Picea abies (L.) Karst.) forest located on a north-facing slope in the French Alps (Tarentaise Valley, Savoy, 45733bN, 6742b E), in the parish of Macot-La-Plagne. The altitude of the 0.8-ha study site ranged from $1535 \mathrm{~m}$ to $1575 \mathrm{~m}$. This site had already been studied by Bernier and Ponge (1994). The vegetation belongs to the Melampyro-sylvatici-Piceetum phytosociological type, generally encountered in the north-western Alps at Mid-altitudes (Gensac 1970, 1988). This forest site was considered as a complex of forest and heath ecosystems. The soil is a siliceous colluvium comprised mainly of quartzite particles, with a $\mathrm{pH}\left(\mathrm{H}_{2} \mathrm{O}\right)$ measured in the top mineral horizon of around 4. The mean slope is about $30 \%$. According to Rovera (1990), the mean annual precipitation is about $1000 \mathrm{~mm}$ at a neighbouring site.

The humus profiles have been described by Bernier and Ponge (1994) and Bernier (1996). Humus nomenclature follows Green et al. (1993).

Bernier and Ponge (1994) recognised nine fundamental units of the forest patchwork. These units, 
called eco-units by Oldeman (1990), were small homogeneous surfaces. Among them, typical stages of the forest cycle and patches of bilberry (Vaccinium myrtillus L.) heath could be distinguished.

Forest eco-units sensu stricto were characterised by the age of spruce trees (which varied from 5 years to 15 years around the mean age in a given eco-unit) and, before canopy closure, by a herbaceous layer comprised mainly of Luzula sylvatica (Huds.), Deschampsia flexuosa (L.), Melampyrum sylvaticum (L.) and Prenanthes purpurea (L.). Regeneration of spruce takes place in herbaceous eco-units with acid mull humus (André et al. 1990; Bernier and Ponge 1994; Ponge et al. 1994) representing the innovation phase, sensu Oldeman (1990). Further development of spruce results in eco-units with leptomoder humus (Green et al. 1993).

Herbaceous eco-units are encircled by bilberry heath with a humimor humus (Bernier and Ponge 1994; Maubon et al. 1995). At this altitude, the competition between heath and spruce for the colonisation of herbaceous eco-units generally favours the latter. Invasion by heath succeeds when the old spruce eco-units are progressively disrupted by management practices, such as canopy opening to promote natural regeneration. The development of a bilberry heath was always preceded by the appearance of a dense moss carpet.

Bernier and Ponge (1994) demonstrated that contrasting humus forms found under these eco-units were linked with the patchy distribution of earthworm populations. Among the nine eco-units studied by these authors, five were selected for the experiment. General features of these five eco-units are indicated in Table 1. Humus profiles belonging to the mature stage of spruce development exhibited no clear stratification. Bernier and Ponge (1994) described this form as an earthworm mull-like moder, a particular mullmoder (Green et al. 1993) characterised by the deposition of organo-mineral casts of anecic earthworms within the thick top organic layer. This paper focused especially on L. terrestris because this species was observed to be the first geophagous species of earthworms invading moder humus during the adult phase of spruce development.

Experimental design

Humus blocks $(30 \mathrm{~cm}$ x $30 \mathrm{~cm}$ x $30 \mathrm{~cm}$ ) were collected on the field and transferred immediately into 1-mm wire mesh cages (90 cm x $90 \mathrm{~cm}$ basal area and $50 \mathrm{~cm}$ height) with as little disturbance as possible. Cages were covered with a mesh lid to prevent earthworms from escaping and protect them from predators. When present, ground vegetation ( $20 \mathrm{~cm}$ height) was kept intact at the top of the humus blocks. The cages were buried $30 \mathrm{~cm}$ deep so that the surface of the blocks corresponded with the neighbouring ground surface. Humus blocks were 
kept with their complete fauna and some L. terrestris individuals may have been present in addition to the introduced animals.

Six cages were used, five as treatment and one as control. In each of the five cages, nine humus blocks were arranged according to a semi-random pattern. Each humus form was located once in the centre, four times in a side position and four times in a corner position, i.e. in each cage one humus form occurred in the centre and the four others in both corner and side positions. The position changed from one cage to another by circular permutation. In the sixth cage (the control), nine identical mull humus blocks taken from the regeneration ecounit (herbaceous) were arranged similarly. The control was used as a reference for the assessment of mortality due to treatments, and to have a basis for testing for the attractiveness of mull when surrounded by less favourable humus forms. The six cages were installed in a regeneration (herbaceous) eco-unit which was a 15-20 m wide tree-fall gap located just beside the area already mapped by Bernier and Ponge (1994).

Five adult (clitellate) individuals of L. terrestris were deposited on the surface of each of the nine humus blocks in each cage, corresponding to a density of 55.6 individuals (ind.) $\mathrm{m}^{-2}$. This density was about 4 times that found in the herbaceous eco-unit (Table 1) but corresponded to the maximum density of anecic earthworms observed in the same forest (Bernier 1992). The worms had been previously expelled from a nearby meadow site by applying a $2 \%$ formalin solution. Individuals were thoroughly rinsed in fresh water and kept for $24 \mathrm{~h}$ in their original soil before being introduced into the experimental cages. The earthworms were allowed to move freely throughout the humus mosaic. We observed that individuals moved horizontally on the ground for several minutes before burrowing vertically.

The experiment was run from October 1993 to June 1994, summer months being avoided to prevent desiccation of the soil in the cages. During that time, earthworms had the opportunity to move freely from one humus block to another either on the surface or below. At the end of the experiment the cages were opened, the humus blocks were separated and earthworms were immediately fixed in formalin. After transfer to the laboratory, they were counted and weighed with their guts full. The earthworms were identified using Bouché (1972) and Sims and Gerard (1985). No attempt was made to collect cocoons, but the low density of juvenile $L$. terrestris (Table 2) at the end of the experiment indicated a low rate of reproduction during the experiment. 
Single ANOVAs (Sokal and Rohlf 1980) were performed on earthworm abundance, and total and individual biomass in order to test for differences between: (1) herbaceous humus in treatment versus control cages, (2) positions of humus blocks in the cages, (3) humus forms. Only data describing adult and subadult L. terrestris were considered. ANOVA has also been used to test for the significance of the regression between the abundance of L. terrestris at the end of a similar experiment and the amount of several humus components (data from Bernier 1996).

\section{Results}

Table 2 lists earthworms which were collected in the cages at the end of the experiment. The high ratio of adult versus subadult and juvenile L. terrestris suggested that most earthworms were those which were introduced, and that reproduction scarcely occurred. Statistical results are summarised in Table 3. ANOVA demonstrated significant differences between treatments with respect to both L. terrestris density and total biomass and, although to a lesser extent, the mean individual biomass of L. terrestris.

Densities and total biomasses were at a maximum in the herbaceous acid mull treatment $\left(61.8\right.$ ind. $\left.\mathrm{m}^{-2}\right)$ and at a minimum in the leptomoder humus taken from under the 60-year-old spruce trees $\left(6.2\right.$ ind. $\left.\mathrm{m}^{-2}\right)$ (Fig. 1). The three other humus forms were in an intermediate position (mean: 34.5 ind. $\mathrm{m}^{-2}$ ), with no significant differences between them, but they were significantly different from the mull and from the leptomoder. The classification of humus forms indicated by these relationships is in accordance with that suggested by field data (Table 1).

Earthworm individual biomasses differed significantly between a group comprising herbaceous and moss eco-units $(2.7 \mathrm{~g})$ and a group comprising spruce eco-units $(2.1 \mathrm{~g})$ whatever the age of the trees. Earthworms found in the bilberry humus had an intermediate individual biomass (2.3 g; Fig. 1).

ANOVA testing also included the following differences: (1) among treatment cages, (2) between position of humus blocks at the inside of treatment cages, and (3) among herbaceous humus blocks between treatment and control cages. None of the differences proved to be significant (Table 3).

Earthworm mortality during the 9-month experiment was $15.6 \%$ in control compared to $38.2 \%$ in treatment cages. No significant difference was found in earthworm density among herbaceous humus blocks when comparing treatment cages (5.6 worms each) with control cages (4.2 worms). 
The ratio between initial densities in the cages and those in the field at the herbaceous site was 4.2. The final ratio between the latter and the herbaceous humus form of the treatment cages was 4.6. In the bilberry ecounit the ratio of experimental against field densities was 5.7, i.e. of the same order of magnitude. For moss and spruce (160 years old) treatments however, the ratios were respectively 27.8 and 10.6. Good agreement between experimental and field data was found for 60-year-old spruce humus (earthworm densities were extremely low in the experiment and nil in the field).

Table 4 shows that L. terrestris density was negatively correlated $(P \mathrm{p} 0.05)$ with the amount of holorganic fine material, but no correlation could be shown with the total volume of coniferous litter, of organomineral faeces, or of amorphous organic matter linked with minerals. The main departure from this correlation concerned the bilberry humus form which showed a high volume of holorganic fine material, a low volume of recent earthworm faeces, and a low volume of amorphous organic matter linked with minerals given the observed density of L. terrestris in the experimental cages.

\section{Discussion}

This small-scale mosaic experiment demonstrated the strong influence of humus form on L. terrestris distribution. The natural classification of humus forms according to earthworm densities (Bernier and Ponge 1994) was recognised experimentally when animals were allowed to choose between them (Tables 1, 3).

This patchy earthworm distribution can be explained by the perception of humus quality by individual earthworms and there is no need to explain them in terms of long-term population trends such as birth/death rates. A herbaceous mull humus, when surrounded by unfavourable humus forms, did not prove to be more attractive than when surrounded by mull only (control). As the experimental mosaic consisted of small-sized units, the search for more favourable humus conditions by earthworms failed to explain the observed differences. It may be concluded that each humus form is characterised by a species-specific immediate carrying capacity. The bioassay provided an estimate of the maximum density of L. terrestris a given humus form can carry under field conditions. The tree-fall gap where the experiment was installed can be considered as near optimum in the study site. Support for this claim is provided by the insignificant rain and snow interception, the optimal heating of the ground floor and a thick snow cover preventing soil freezing (Coleman et al. 1990) without delaying snowmelt. Moreover, summer drought and predation were avoided in the experimental cages. Thus our measurement of immediate carrying capacity could be considered as close to the potential L. terrestris density 
for a given humus form under field conditions.

Discrepancies between field and experimental data on $L$. terrestris abundance were at a maximum for humus under moss and adult spruce. Bernier and Ponge (1994) showed that moss eco-units were restricted to small gaps issuing from the felling of individual trees for timber within eco-units densely populated by adult spruce tree. These two kinds of units were strongly influenced by adult trees roots systems and crowns, with the result that drought must be a feature common to these eco-units. An additional explanation could be the transient nature of the humus profile developed under moss and adult spruce trees, i.e. by anecic earthworms in a colonising stage (Bernier and Ponge 1994), so that their potential capacity could be far higher than the observed field densities. Support for this hypothesis is given by the step-by-step colonising process observed by Marinissen and Van den Bosch (1992) in newly reclaimed polders. The present experimental design has certainly been improved with respect to some of the critical factors such as water availability and heat.

According to Bernier and Ponge (1994), the main humus micromorphological change occurring from young to adult spruce stands was the increase in organo-mineral earthworm faeces. As L. terrestris was the only geophagous earthworm observed, these faeces mainly originated from this species. We may wonder whether this animal species can improve, by its own efforts, through the accumulation of organo-mineral faeces, the condition of the humus profile. Spruce ageing may initiate improvement in litter quality and the soil's acid/base balance. Staff (1987) explained differences in beech litter decomposition rates between rich and poor sites by the acid/base balance of the soil, the chemical composition of litter remaining constant. Similar results were obtained after earthworms had been introduced into mor humus whether limed or not (Robinson et al. 1991, 1992) and comparisons were made with a meadow mull. When the ionic balance of mor humus was restored, no differences could be discerned between this and mull humus.

The density of L. terrestris in experimental cages was of the same order of magnitude as field densities reached in bilberry and adult spruce eco-units. The field density was even higher than the experimental one with respect to humus from the bilberry heath (Table 1). Surprisingly, the humus form was an earthworm mull-like moder under adult spruce and a humimor under bilberry. Such discrepancies between humus form and $L$. terrestris distribution led to the conclusion that this species may not always be geophagous (Table 4). The bilberry heathland could be characterised by the adoption of an epigeic habit by L. terrestris, which usually behaves as an anecic species (Bouché 1972). Such plasticity in earthworm behaviour can be considered as contributing to the power of this species to increase its distribution in heterogeneous environments. 
Acknowledgements We are indebted to M. Coppi for field assistance, to the La Plagne skiing resort for technical support and to the French National Office of Forests (O.N.F.) for use of the study sites.

\section{References}

André J, Gensac P, Gautier M (1990) La régénération dans la pessière à myrtille. Description préliminaire de deux stations dans les alpes septentrionales internes (in French). Bull Ecol 21:51-61

Bal L (1982) Zoological ripening of soils. PUDOC, Wageningen

Basker A, Kirkman JH, Macgregor AN (1994) Changes in potassium availability and other soil properties due to soil ingestion by earthworms. Biol Fertil Soils 17:154-158

Bernier N (1992) Modification de la forme d'humus au cours du cycle sylvogénétique d'une pessière d'altitude (in French). D.E.A., Université de Paris XI, Orsay

Bernier N (1996) Altitudinal changes in humus form dynamics in a spruce forest at the montane level. Plant Soil $178: 1-28$

Bernier N, Ponge JF (1994) Humus form dynamics during the sylvogenetic cycle in a mountain spruce forest. Soil Biol Biochem 26:183-220

Bornebusch CH (1930) The fauna of forest soil. Forst Forsøgsvaes Dan 11:1-158

Bouché MB (1972) Lombriciens de France. Ecologie et systématique (in French). INRA, Paris

Coleman DC, Ingham ER, Hunt HW, Elliott ET, Reid CPP, Moore JC (1990) Seasonal and faunal effects on decomposition in semiarid prairie, meadow and lodgepole pine forest. Pedobiologia 34:207-219

Gensac P (1970) Les pessières de Tarentaise comparées aux autres pessières alpestres (in French). Veröff Geobot Inst Eidg Tech Hochsch Stift Rübel Zürich 43:104-139

Gensac P (1988) Types de pessière et régénération en Moyenne Tarentaise (Savoie) (in French). Rev For Fr $40: 285-296$ 
Green RN, Trowbridge RL, Klinka K (1993) Towards a taxonomic classification of humus forms. For Sci Monogr 29:1-49

Lee KE (1985) Earthworms. Their ecology and relationships with soils and land use. Academic Press, Sydney

Marinissen JCY, Van den Bosch F (1992) Colonization of new habitats by earthworms. Oecologia 91:371-376

Maubon M, Ponge JF, André J (1995) The dynamics of Vaccinium myrtillus patches in mountain spruce forest. J Veg Sci 6:343-348

Muys B, Lust N (1992) Inventory of the earthworm communities and the state of litter decomposition in the forests of Flanders, Belgium, and its implications for forest management. Soil Biol Biochem 24:16771681

Oldeman RRA (1990) Forests: elements of silvology. Springer, Berlin Heidelberg New York

Ponge JF, André J, Bernier N, Gallet C (1994) La régénération naturelle: connaissances actuelles. Le cas de l'épicéa en forêt de Macot (Savoie) (in French). Rev For Fr 46:25-45

Robinson CH, Piearce TG, Ineson P (1991) Burrowing and soil consumption by earthworms in limed and unlimed soils from Picea sitchensis plantations. Pedobiologia 35:360-367

Robinson CH, Piearce TG, Ineson P, Dickson DA, Nys C (1992) Earthworm communities of limed coniferous soils: field observations and implications for forest management. For Ecol Manage 55:117-134

Rovera G (1990) Géomorphologie dynamique et aménagement des versants en moyenne Tarentaise (Savoie; communes de Granier, Aime, Mâcot-La-Plagne et Champagny). Une contribution à l'étude de l'érosion naturelle et anthropique des Alpes (in French). PhD thesis, Université de Grenoble

Sims RW, Gerard BM (1985) Earthworms. Keys and notes for the identification and study of the species. Brill and Backhuys, London

Sokal RR, Rohlf FJ (1980) Biometry. The principles and practice of statistics in biological research. Freeman, San Francisco

Staff H (1987) Foliage litter turnover and earthworm populations in three beech forests of contrasting soil and vegetation types. Oecologia 72:58-64 


\section{Legends of figures}

Fig. 1 Density, total biomass and mean individual biomass of L. terrestris in the experimental humus mosaic (five treatment cages) at the end of experiment (see Table 3 for statistical tests). Data from control cage (herbaceous) have not been used in this chart. $Y R$ Years old, ind. individuals 
Table 1 Natural vegetation and humus features, and Lumbricus terrestris populations ${ }^{\mathrm{a}}$ in the five eco-units used for the experiment. ind. Individuals

\begin{tabular}{|c|c|c|c|c|c|}
\hline & Herbaceous & $\begin{array}{l}\text { Spruce (60 year } \\
\text { old) }\end{array}$ & $\begin{array}{l}\text { Spruce ( } 160 \text { year } \\
\text { old) }\end{array}$ & Moss & $\begin{array}{l}\text { Bilberry } \\
\text { heath }\end{array}$ \\
\hline \multicolumn{6}{|l|}{ Vegetation } \\
\hline Moss layer & + & 0 & 0 & ++ & ++ \\
\hline \multicolumn{6}{|l|}{ Herb layer } \\
\hline Luzula sylvatica & ++ & 0 & 0 & $+/-$ & $+/-$ \\
\hline Deschampsia flexuosa & ++ & 0 & 0 & $+1-$ & $+1-$ \\
\hline Melampyrum sylvaticum & ++ & 0 & 0 & $+/-$ & $+/-$ \\
\hline Prenanthes purpurea & ++ & 0 & 0 & $+1-$ & 0 \\
\hline Oxalis acetosella & $+/-$ & 0 & + & ++ & $+/-$ \\
\hline \multicolumn{6}{|l|}{ Shrub layer } \\
\hline Vaccinium myrtillus & $+/-$ & 0 & 0 & + & ++ \\
\hline V. vitis-idaea & $+/-$ & 0 & 0 & + & ++ \\
\hline \multicolumn{6}{|l|}{ Spruce trees } \\
\hline Mean age (years) & 10 & 53 & 171 & - & - \\
\hline Maximum height (m) & 1.5 & 19 & 30 & - & - \\
\hline \multicolumn{6}{|l|}{ Humus } \\
\hline $\mathrm{L}(\mathrm{cm})$ & 3 & 1 & 2 (mixed with A1) & 3 & 4 \\
\hline $\mathrm{F}(\mathrm{cm})$ & 0 & 2 & 3 (mixed with A1) & 2 & 3 \\
\hline $\mathrm{H}(\mathrm{cm})$ & 0 & 3 & 8 (mixed with A1) & 0 & 4 \\
\hline A1 & 10 & 0 & 13 (mixed with $\mathrm{H}$ ) & 0 & 0 \\
\hline Humus form (Green et al. 1993) & Vermimull & Leptomoder & Mullmoder & Mormoder & Humimor \\
\hline $\begin{array}{l}\text { L. terrestris (ind. } \mathrm{m}^{-2} \text { ) (Bernier and Ponge } \\
\text { 1994) }\end{array}$ & 13.33 & 0 & 2.67 & 1.33 & 6.67 \\
\hline
\end{tabular}

${ }^{\mathrm{a}} 0=$ Absent,$+/-=$ scarce,$+=$ fairly abundant, $++=$ abundant 
Table 2 Total number of earthworms at the end of the experiment

\begin{tabular}{lr}
\hline Species & No. \\
\hline Lumbricus terrestris (L.) & 149 \\
Adult & 28 \\
Subadult & 15 \\
Juvenile & \\
Lumbricus castaneus (Savigny) & 11 \\
Adult & 3 \\
Subadult & 1 \\
Juvenile & 11 \\
Dendrodrilus rubidium (Savigny) & \\
Aporrectodea icterica (Savigny) & 4 \\
A. caliginosa (Savigny) & 2 \\
A. rosea (Savigny) & 1 \\
Aporrectodea spp. (juveniles) & 18 \\
Octolasion sp. & 1 \\
\hline
\end{tabular}


Table 3 ANOVA tests on L. terrestris distribution within an experimental mosaic of humus forms. Herb. herbaceous, Bil. bilberry, Spr. (160) 160-year-old spruce, Spr. (60) 60-year-old spruce, NS non significant

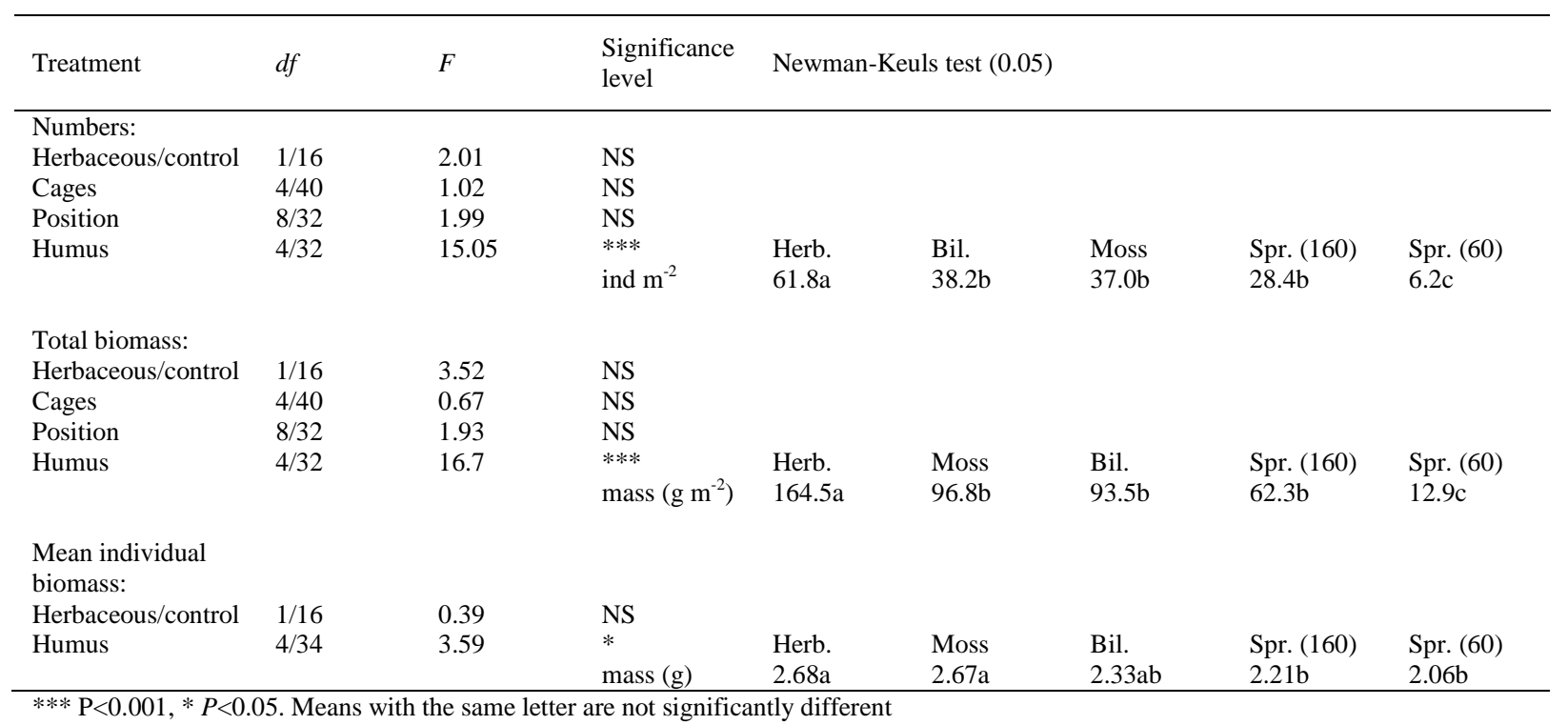


Table 4 ANOVA tests for regression between the abundance of L. terrestris at the end of the experiment and humus components (from Bernier 1996). For abbreviations, see Tables 1 and 3

\begin{tabular}{llllllll}
\hline & Herb. & Bil. & Moss & Spr. (160) & Spr. (60) & $F$ ratio & $P$ \\
\hline L. terrestris $\left(\right.$ ind. $\left.\mathrm{m}^{-2}\right)$ & 61.8 & 38.2 & 37 & 28.4 & 6.2 & & \\
Coniferous litter $\left(\mathrm{m}^{3} \mathrm{ha}^{-1}\right)$ & 14.5 & 3.8 & 7.6 & 20.9 & 40.6 & 3.180 & 0.173 \\
Holorganic fine material $\left(\mathrm{m}^{3} \mathrm{ha}^{-1}\right)$ & 1.7 & 21.7 & 3.2 & 18.6 & 45.6 & 10.382 & 0.049 \\
Recent earthworm faeces $\left(\mathrm{m}^{3} \mathrm{ha}^{-1}\right)$ & 66.0 & 0.3 & 1.6 & 23.6 & 8.5 & 2.293 & 0.227 \\
Amorphous organic matter linked with minerals $\left(\mathrm{m}^{3} \mathrm{ha}^{-1}\right)$ & 37.9 & 0.05 & 0.9 & 2.5 & 1.4 & 3.899 & 0.143 \\
\hline
\end{tabular}




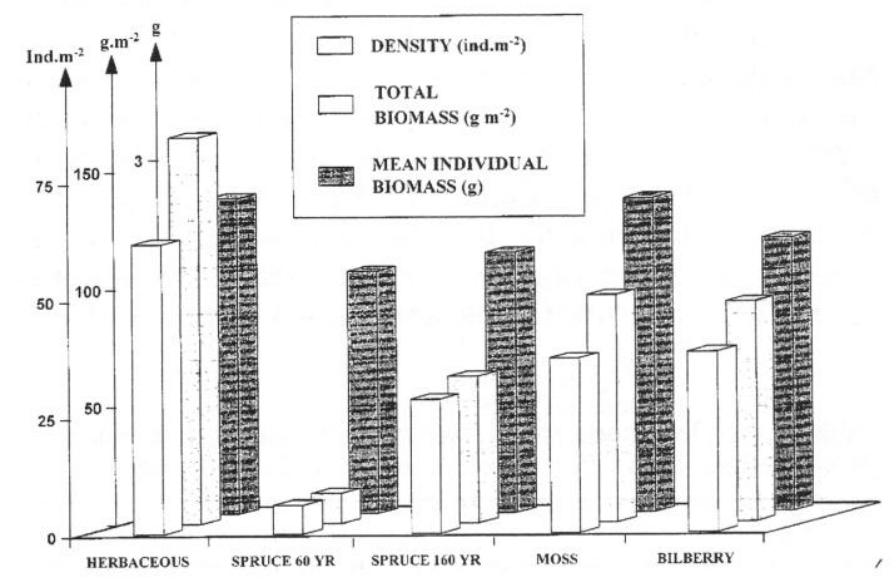

Fig. 1 